\title{
Evaluation of some interleukins and immunomodulatory factors in Iraqi scabies patients
}

\author{
Nora.D. Al-Musawi ${ }^{1}$ Nagham Y.Al-Bayati ${ }^{1}$ Munther, Hussain ${ }^{2}$ \\ ${ }^{1}$ College of Education for Pure Science, University of Diyala, Iraq \\ ${ }^{2}$ King's College London, London, UK \\ E-mail: munther.hussain@ kcl.ac.uk
}

\begin{abstract}
Scabies is a contagious skin infection, caused by Sarcoptesscabiei. It is one of a neglected parasitic disease. It causes complications that lead to inflammatory and allergic immune response.This study was designed to obtain the role of some cytokines in scabies patients and compare their levels with dermal diseases patients and control (healthy).

The study included one hundred and three patients infected with scabies, seven dermal disease patients (positive controls) as well as 34 healthy individual as control group. The blood samples were collected from scabies and dermal disease patients as well as the control groups.Enzyme linked immunosorbent assay(ELISA) was used to measure Interleukine-4 (IL-4), Interleukin -8 (IL-8), Interleukin-17A (IL-17A), Tumor necrosis factor- $\alpha$ (TNF- $\alpha)$, Interferon- $\gamma$ (IFN- $\gamma)$, Monocyte Chemotactic Protein-1 (MCP-1) and Macrophage Inflammatory Protein-1- $\alpha$ (MIP-1- $\alpha$ ) in the serum of scabies patients, dermal disease patients and healthy individuals.

The results showed that IL-4, IL-8, IL-17A and TNF- $\alpha$ was higher in scabies patients than in other groups (positive control and healthy), with no significant differences. While both of MIP- $\alpha$ and MCP-1 were higher in scabies patients compared with healthy group, with significant differences. MIP- $\alpha$ was higher in dermal patients individuals than in scabies patients. TNF- $\alpha$ was lower in scabies patients than in healthy group but higher than in dermal disease patient group.There was positive correlation between IL-17A and each of IL-8, TNF- $\alpha$, MCP- 1 and between IL- 8 and both of IL-17A and MCP-1, while there was negative correlation between MIP-1- $\alpha$ and both of IL-4 and MCP-1.The results suggested that the scabies infection may induce the systemic and inflammatory immune response.
\end{abstract}

Keywords: Scabies, IL-4, IL-8, IL-17A, TNF- $\alpha$, IFN- $\gamma$, MCP-1, MIP-1- $\alpha$

\section{Introduction:}

Scabies is a disease affecting both sexes at different ages for all ethnic and socio- economic levels without exception (W.H.O., 2005). It remains a certain health 
problem causes a serious economic loss for cattle breeders and farm animals(Jordan $\&$ Verma, 2014). It is cutaneous infestation caused by a tiny obligate parasite belong to scabies mites (Sarcoptesscabiei)affects various kinds of domestic and wild animals (Pence \&Veckermann, 2002; Walton et al., 2004).

Despite of Sarcoptesscabiei worldwide spread and infects over than 40 kinds of mammals including human, it still considersa neglected parasitic disease.The cold weather and high population density are a crucial factors for increase prevalence of disease (Daown et al.,1999; Poulat\&Nasirian, 2007). Low temperatures and high relative humidity are suitable environment conditions for increase mites activity and infection (Arlian, 1989; White, 2009).

Scabies has been found to be more prevalent in both developing and developed countries andhas high incidence in crowded and poor populations, such as prisons and civil institutions, nursing and orphans centers as well as army andemigrant and immigrant camps (Routh et al.,1994). Individuals with scabies suffer from severe itching mediated through hypersensitivity reaction caused by mite's antigens and its secretion(Walton, et al., 2004).Liu, et al., (2014) confirmed that mitesmay induce an inflammatory and cell-mediated immune responses in its host. Other studies indicated that Scabies induces immune allergic responseand keratinocytes and lead to secretion of its some cytokines (Arlian et al., 2003; Walton, et al., 2010) in the other hand, AlMusawi (2014) referred that the disease stimulates both humoral and cellular immune responses.

A numerous studies focus on the humoral and cellular immune response, most of these studies conducted on laboratory animals (mice, rabbits, pigs), either exposed to the parasite antigens or infected with parasite itself (Smets\&Vercruysse, 2000; Mounsey, et al.,2015).Despite the availability of a lot of information on the immunology of scabies in human, there is a dearth of studies that address the immunological changes that occur in human systemic immuneresponse. Previously literature obtained that most common cells in the site of lesion areinflammatory cells (eosinophils, lymphocytes and macrophages), while the most predominant cells are Tlymphocyteswhich play a main role in the activation and regulation of immune responses by inducing cytokine production (Bhat el al., 2017).Keratinocytes may also produce pro-inflammatory and immunomodulatory cytokines and they consider to be responsible for systemic effects (Al-Musawi et al., 2014). The present study was conducted to determine IL-4, IL-17A, IL-8, TNF- $\alpha$, IFN- $\gamma$, MCP-1, MIP-1- $\alpha$ levels inscabies patients, dermal disease patients and healthy (control) in Diyala province and to compare cytokines levels in all studied groups. 


\section{Material and Methods:}

2-1. Subjects:The study samples were collected from March to May 2016.One hundred and three patients infected with scabies,(50 males and 53 females), their ages between 1-90 years were including in the present study. The diseaseswere diagnosed by dermatologist, the study included also sevendermal disease patients (five males and two females).Their ages between 2-54 years as apositive control, as well as the healthy group (control) included 34 persons (21 males and 13 females) their ages between (5-63) years. It has been confirmed that all group individuals did not have allergic diseases, helminthic infections, secondary infection, previous attack with scabies, and/or getting any antihistamines drugs were included for cytokines assays.

2-2. Blood sample collection:The blood sampleswere collected from scabies and dermal disease patients as well as the control groups. Five $\mathrm{ml}$ of venous blood was taken and leftto clot in room temperaturefor 30-60 minutes. Serum was separated by centrifuging at $3000 \mathrm{rpm}$ for five minutes. Sera were divided into four parts using Eppendorf tubes $\left(0.5 \mathrm{ml}\right.$ per each). The samples were kept at $-20 \mathrm{C}^{\circ}$ until it uses.

2-3.Clinical examination: The clinical examination had been done by the dermatologistsin hospital and the scabies and other dermal diseases were diagnosedaccording to clinical features.

2-4.The cytokines assay:The cytokines werequantitatively measured in allgroups individuals. These cytokines were human IL-4, IL-8, IL-17A, TNF- $\alpha$, IFN- $\gamma$, MCP1 and MIP-1- $\alpha$ by using enzyme linked immunosorbent assay, according to manufacturers' instruction, PeproTech Com, UK.

2-5.Statistical Analysis: The results were statistically analyzed using Statistical Package for Social Sciences (SPSS),version 15. Data were expressed as mean \pm standard error(SE). Duncan's multiple range test was used for comparison among several means. Pearson Correlation ( $r$ ) wasused to determine the correlation between criteria. $\mathrm{P}$-value $\leq 0.05$ was considered statistically significant.

\section{Results:}

3-1.Cytokines levels:The results of the present study showedhigh level concentration of cytokine IL-4 in scabies patients $(84.101 \pm 23.844 \mathrm{pg} / \mathrm{ml})$ comparing with its levels in dermal diseases patients $(77.871 \pm 45.242 \mathrm{pg} / \mathrm{ml})$, and the control group (49.106 $\pm 16.044 \mathrm{pg} / \mathrm{ml})$ but without significant differences as shown in Table1. 
Table (1): Cytokines and chemokines level among individuals infected with scabies, dermal diseases and healthy persons.

\begin{tabular}{|c|c|c|c|}
\hline $\begin{array}{l}\text { Cytokines and } \\
\text { chemokines }\end{array}$ & Groups & $\begin{array}{c}\text { Mean } \pm \text { SE } \\
\mathrm{pg} / \mathrm{ml}\end{array}$ & $\rho$-value \\
\hline \multirow{3}{*}{ IL-4 } & Scabies patients & $84.101 \pm 23.844$ & \multirow{3}{*}{$0.812(\mathrm{NS})$} \\
\hline & Dermal diseases patients & $77.871 \pm 45.242$ & \\
\hline & Control & $49.106 \pm 16.044$ & \\
\hline \multirow{3}{*}{ IL-8 } & Scabies patients & $33.746 \pm 9.996$ & \multirow{3}{*}{$0.755(\mathrm{NS})$} \\
\hline & Dermal diseases patients & $34.742 \pm 14.642$ & \\
\hline & Control & $14.143 \pm 4.379$ & \\
\hline \multirow{3}{*}{ IL-17A } & Scabies patients & $49.738 \pm 9.768$ & \multirow{3}{*}{$0.651(\mathrm{NS})$} \\
\hline & Dermal diseases patients & $33.285 \pm 14.842$ & \\
\hline & Control & $44.817 \pm 7.694$ & \\
\hline \multirow{3}{*}{ IFN- $\gamma$} & Scabies patients & $177.864 \pm 10.626$ & \multirow{3}{*}{$0.042 *$} \\
\hline & Dermal diseases patients & $86.142 \pm 11.244$ & \\
\hline & Control & $180.705 \pm 19.114$ & \\
\hline \multirow{3}{*}{ TNF- $\alpha$} & Scabies patients & $75.306 \pm 23.321$ & \multirow{3}{*}{$0.785(\mathrm{NS})$} \\
\hline & Dermal diseases patients & $49.028 \pm 23.361$ & \\
\hline & Control & $55.217 \pm 17.990$ & \\
\hline \multirow{3}{*}{ MCP-1 } & Scabies patients & $253.466 \pm 18.979$ & \multirow{3}{*}{$0.01 * *$} \\
\hline & Dermal diseases patients & $332.714 \pm 45.531$ & \\
\hline & Control & $185.750 \pm 32.543$ & \\
\hline \multirow{3}{*}{ MIP-1- $\alpha$} & Scabies patients & $601.194 \pm 140.528$ & \multirow{3}{*}{$0.023 *$} \\
\hline & Dermal diseases patients & $2426.857 \pm 1352.358$ & \\
\hline & Control & $491.706 \pm 488.358$ & \\
\hline
\end{tabular}

* Significant differences in $\mathbf{p}<0.05$.

** Significant differences in $\mathbf{p}<0.001$

The results showedelevation in IL-8 concentration in both scabies and dermal diseases serum $(33.746 \pm 9.996$ and $34.742 \quad \pm 14.642 \mathrm{pg} / \mathrm{ml}$, respectively)comparedwith in healthy group $(14.143 \pm 4.379 \mathrm{pg} / \mathrm{ml})$, while IL-17A was increase in scabies patients serum $(49.738 \pm 9.768 \mathrm{pg} / \mathrm{ml})$ and healthy group $(44.817 \pm 7.694 \mathrm{pg} / \mathrm{ml})$ compared with dermal diseases patients $(33.285 \pm 14.842$ $\mathrm{pg} / \mathrm{ml}$ )as sowed in Table 1 .

IFN- $\gamma$ wasdecreasein scabies patients and dermal patients diseases comparing tohealthy group $(177.864 \pm 10.626 \mathrm{pg} / \mathrm{ml}, 86.142 \pm 11.244 \mathrm{pg} / \mathrm{ml}, 180.705 \pm$ $19.114 \mathrm{pg} / \mathrm{ml}$, respectively). The present study showed increase in TNF- $\alpha$ levels in scabies patients comparing with dermal diseases patients andhealthy group (75.306 \pm $23.321 \mathrm{pg} / \mathrm{ml}, 49.028 \pm 23.361 \mathrm{pg} / \mathrm{ml}, 55.217 \pm 14.990 \mathrm{pg} / \mathrm{ml}$, respectively)

The current study showed increase in both of MCP-1 and MIP-1-ascabies and dermal diseases patients serum comparing with healthy group $(253.466 \pm 18.979 \mathrm{pg} / \mathrm{ml}$, $332.714 \pm 45.531 \mathrm{pg} / \mathrm{mland} 185.750 \pm 32.543 \mathrm{pg} / \mathrm{mlfor} \mathrm{MCP}-1$ and $601.194 \pm$ 
$140.528 \mathrm{pg} / \mathrm{ml}, 2426.857 \pm 1351.358 \mathrm{pg} / \mathrm{ml}$ and $601.194 \pm 140.528 \mathrm{pg} / \mathrm{ml}$, respectively)

\section{3-2.Correlation of cytokines in scabies patients:}

The current study showedthat there was positive correlation between IL-17A and each of IL-8, TNF- $\alpha$, MCP-1 and between IL-8 and both of IL-17A and MCP-1, while there was negative correlation between MIP-1- $\alpha$ and both of IL-4 and MCP-1 as showed in table (2):

Table (2): Cytokines correlation among 103 scabies patients

\begin{tabular}{|c|c|c|c|c|c|c|c|}
\hline & IL-4 & IL-8 & IL-17A & IFN- $\gamma$ & TNF- $\alpha$ & MCP-1 & MIP-1- $\alpha$ \\
\hline IL-4 & 1 & & & & & & \\
\hline IL-8 & $0.339^{* *}$ & 1 & & & & & \\
\hline IL-17A & 0.011 & $0.731^{* *}$ & 1 & & & & \\
\hline IFN- $\gamma$ & $0.285^{* *}$ & 0.128 & 1.142 & 1 & & & \\
\hline TNF- $\alpha$ & 0.070 & 0.093 & $0.288^{* *}$ & 0.110 & 1 & & \\
\hline MCP-1 & 0.096 & $0.386^{* *}$ & $0.294^{* *}$ & 0.132 & 0.039 & 1 & \\
\hline MIP-1- $\alpha$ & $0.019-$ & 0.050 & 0.025 & 0.056 & $0.351^{* *}$ & $0.008-$ & 1 \\
\hline ** Correlation in P- value 0.01
\end{tabular}

\section{Discussion:}

The current study showed increase in the level of IL-4 in scabies patients serum comparing with dermal diseases patients and healthy group (control). This results agree with Karthikeyan\&Ragunatha (2011) , Al-Musawi, et al., (2014) and Mounsey, et al., (2015). They mentioned that there is an increase in IL-4 levels in scabies patients comparing with the healthy group while Arlian et al., (2006) did not record this cytokine in scabies patients. In the other hand Walton, et al., (2010) showed there is no significant differences in the levels of IL-4 between the scabies patients and healthy groups. The increase of this cytokine (IL-4) (which is one of the cytokines expression of Th2 ) indicates that Th2 cells stimulate in scabies infestation. This cytokince regulates the production of $\operatorname{IgE}$ and control the production of mast cell and eosinophils which are stimulating in hypersensitivity reaction (as shown in histological changes obtained in previous study for Almusawi et al, 2018). In addition the stimulating mast cell and eosinophils produce IL-4 (Zamorano et al, 2003). On the other hand, IL-4 play important rols as chemotactic immune response in skin lesion. Many other histological studies use human and animal models had been detected mast cells and basophils in skin lesion of human and animals infected with scabies (Amer et al ., 1995; Ito et al.,2011; Nimmervoll et a 1., 2013; Mounsey et al.,2015 ). Activated mast cells and basophils rapidly produce some cytokines 
(including Th2 cytokines IL-4) which are the main molecules as well as that the cytotoxicity against keratinocytes mostly release cytokines responsible for amplify the allergic Th2-type inflammatory response (Bhat et al., 2017 ).

The present study obtained that the levels of IL-8 was increase in scabies and dermal disease patients comparing with healthy group, this results agree with Morgan \&Arlian (2010) who showed that monocytes secret IL-8 in high levels after adding Sarcoptesscabiei antigen to the culture media or when exposed skin cells culture media (EpiDerm EFT-400 full-thickness Human Skin Equivalents) to extract of parasites. IL-8 secretes from skin cells (keratinocytes, fibroblasts, and macrophages), and the secretion of IL-8 increase in dermal diseases (Coondoo,2012).

The increase in IL-17A level in scabies patients in the present study agrees with Liu, et al. (2014) and Mounsey, et al. (2015) who reported that IL-17-A was increased in pigs infested with scabies. IL-17A is pro-inflammatory cytokine related with many hypersensitivity, host defense and inflammation diseases (Jin and Dong, 2013). Its secreted from mast cells and Th17 cells .Arlian et al., 2007, Martin et al., (2014) and Mounsey et al., (2015) referred that this cytokine related with IL-23 secreted by dendritic cells, macrophages and keratinocytes, all these cells are recorded in scabies cases, supporting an IL-17environment (Arlian et al., 2007; Martin et al 2014). The present study showed that INF- $\gamma$ was decrease in scabies patients comparing with healthy and patients with dermal diseases groups. This results agree with Zamorano, Walton et al . (20032010) who obtained that there was a clear decreased of IFN- $\gamma$ production was observed in scabies patients as a response to parasite cystine proteinase. Arlian et al, (2007) referred that expose mice to live mites lead to decrease the expression of IFN- $\gamma$ and suggest that the mite produce molecules reduce expression of immune cytokines and chemokine including IFN- $\gamma$. In the other hand, Arican, et al. (2005) showed that the cells production of this cytokine downregulates in the blood of dermal disease (such as psoriasis) and lead to aggravation of disease, in the contrary, some studies reported that there was increase in INF- $\gamma$ in dermal diseases combined with macrophage (Hua, et al ., 2006; Huard, et al., 2017 ).

In the present study TNF- $\alpha$ level was increase in scabies patients serum and decrease among dermal diseases patients. This result agree with Arlian et al (2004) Morsy, et al., (1995) who demonstrated that TNF- $\alpha$ was increased in monocyte culture media when exposing to culture to scabies mite extract which indicate the ability of the molecules in the extract's molecules to modulate the monocytes and dendritic cells functions. Likewise Portugal, et al. (2007), Al-Musawi, et al . (2014) and Abd ElAal, et al. (2016) indicated a higher levels of TNF- $\alpha$ among individuals infested with scabies and suggested that there was an important role of TNF- $\alpha$ in human scabies 
control . While Portugal, et al. (2007) Levi - Schaffer, et al., (1998) showed that TNF- $\alpha$ production may be due to the physical stimulation by parasite's burrowing in the skin that lead to inflammatory response., Levi - Schaffer, et al., (1998) Mulline, et al . (2009) Morgan, et al., (2013) and Al-Musawi, et al., (2014) suggested that TNF- $\alpha$ associated with presence of eosinophils and its ability to active this cells in scabies patients.

The present results showed increase in MCP-1 level in scabies patient serum. This result agrees with Morgan \&Arlian (2010) who indicated that MCP-1 increase in the culture media using (human skin equivalent) human skin cells was that exposed to mite extract and suggested that this result may be due to the physical stimulation resulting from extract's molecules borrowing by the mites which lead to produce this cytokine. Another study observed that salivary secretions and mite's antigen stimulate MCP-1 which in turn attracts lymphocytes, monocytes and dendritic cells to lesion areas result in inflammatory reactions (Kobets, et al., 2012).

This study showed increasing in MIP-1 $\alpha$ among dermal diseases patient and scabies patients. These This results agree with Morgam et al, (2013) Kobets, et al. (2012) who suggested that in vivovitro, the interplay between cell media culture and the antigens of parasite is responsible for increase of this some chemokines also including MIP- $1 \alpha$, re MIP- $2 \alpha$ and M3P- $1 \alpha$ and suggested that the antigen of the parasite stimulates inflammatory immune response. In the other hand ,Kobets, et al. (2012) suggest that the increase of MIP- $1 \alpha$ related with increase of TNF- $\alpha$. MIP- $1 \alpha$ was increase in cutaneous leishmaniasis patients this agree with Al-Saadi (2014) who showed increasing this cytokine among individual infected with cutaneous leishmaniasis and related with skin lesion numbers. MIP-1 $\alpha$ produce by macrophages and dendritic cells where Leishmaniatropica proliferation proliferate and increasing numbers of this parasite leading to rupture of these cells and release their contents (including (CCl3) MIP-1 $\alpha$ ) . (Kobets, et al.,2012).

The current study showed that there was positive correlation between IL-17A and each of IL-8, TNF- $\alpha$, MCP-1 and between IL-8 and both of IL-17A and MCP-1, while there was negative correlation between MIP-1- $\alpha$ and both of IL-4 and MCP-1 . These may reflect the complex associate relation in immune response and help explain the delayed inflammatory reaction to infestation with S. scabiei which needs further investigation and study .

\section{Conclusion}

The study concluded that the scabies infection may induce the systemic and inflammatory immune response. 


\section{References}

-Abd El-Aal, A.A.; Hassan, M. A.; Gawdat; M.I.; Ali, M.A. \&Barakat, M. (2016). Immunomodulatory impression of anti and pro- inflammatory cytokines relation to humeral immunity in human scabies. International Journal of Immunopathology and Pharmacology, 29(2): 188-194.

-Amer, M.; Mostafa, F.F.; Nasr, A.N.; and el-Harras, M. (1995). The role of mast cells in treatment of scabies. International Journal of Dermatology, 34(3):186-9.

-Al-Musawi, M.A.A. (2014). Evaluation of immune response in scabietic patients in Najaf Governorate. PH. D. Thesis, Kufa University, College of Science, Department of Biology: 102P.

-Al-Musawi, M.M.; Hasan, H.R. and Maluk, A.H,(2014). Relationship between Th1, Th2 immune response and serum SOD activity in scabies. Journal of Advanced Biomedical and Pathobiology Research, 4(1):1-15.

-Al-Saadi; K.H.R, (2014).Cytokines measurements IL-10, IL-17A, IL-4, MIP-1- $\alpha$ among individuals infected with leishmaniasis, M.Sc., College of Education For Pure Sciences, University of Diyala, 200p.

-Arican, O.; Arai, M., Sasmaz ; S. Ciragil, p.(2005). Serum levels of TNF- $\alpha$, IFN- $\gamma$, IL-6, IL-8, IL-12, IL-17 and IL18 in patients with active psoriasis and correlation with disease severity. Mediators of Inflammation, 2005(5):273-279.

-Arlian, L.G. (1989). Biology, host relation and epidemiology of Sarcoptesscabiei. Annual Review of Entomology, 34(1): 139-161.

-Arlian, L.G.; Fall, N. \& Morgan, M.S. (2007). In vivo evidence that Sarcoptesscabiei (Acari: Sarcoptidae) is the source of molecule, that modulate splenic gene expression. Journal of Medical Entomology. 44(6):1054-1063.

-Arlian, L.G.; Morgan, M.S. and Neal, J.S. (2004). Extracts of scabies mites (Sarcoptidae: Sarcoptesscabiei) modulate cytokine expression by human peripheral blood mononuclear cells and dendritic cells. Journal of Medical Entomology. 41 (1):69-73.

-Arlian, L.G.; Morgan, M.S \& Paul, C.C. (2006). Evidence that scabies mites (Acari, sarcoptidae) influence production of interleukine-10 and function of $\mathrm{T}$ regulatory cells (Trl) in humans. Journal of Medical Entomology, 23(2): 283287. 
-Arlian, L.G.; Morgan, M.S.\& Neal, J.S. (2003). Modulation of cytokines expression in human keratinocytes and fibroblasts by extract scabies mites. The American Journal of tropical Medicine and Hygiene, 69(6):652-656.

-Bhat, S.A.; Mounsey, K.E.; Liu, X. \& Walton, S. F. (2017). Host immune responses to the itch mite, Sarcoptesscabiei, in humans. Parasites and Vectors,10(1): 10:385 DOI 10.1186/s13071-017-2320-4

-Coondoo, A. (2012). The role of cytokines in the pathomechanism of cutaneous disorder. Indian Journal of Dermatology, 57(2):90-96.

-Downs, A.M.; Harvey, I. \& Kennedy, C.T. (1999). The epidemiology of head lice and scabies in UK. Epidemiology and Infection, 122(3):471-477.

-Hua, Z., Feil, H. \&Mingming, X. (2006). Evaluation and interferon of serum and skin lesion levels leukotrienes in patients with eczema. Prostaglandins leukotrienes and Essential Fatty Acids, 75(1): 51-55.

-Huard, C.; Gulla, S.V.; Bennett, D.V.; Coyle, A.J.; Velugels, R.A \& Greenberg, S.A. (2017). Correlation of cutaneous disease activity with type interferon gene signature and interferon- $\beta$ in dermatomysil. British Journal of Dermatology, 175(5): 1224-1230.

-Ito. Y.; Satoh, T.; Takayama, K.; Miyagishi, C.; Walls, A.F. and Yokozeki, H. (2011). Basophil recruitment and activation in inflammatory skin diseases. Allergy, 66(8):1107-13

-Jin, W. and Dong, C.(2013). IL-17 cytokines in immunity and inflammation.Emerging Microbes and Infections, 2(9): e60.

-Jordan, E.L. \&Verma, S. P. (2014). Invertebrate zoology. Chand Company Ltd, New Delhi: $1127 \mathrm{p}$.

-Karthikeyan, K \&Ragunatha, S. (2011). Update on scabies and pediculosis in children, In :Inamadar, A.C. and Palit, A. (Edrs.) Advance in pediatric dermatology. Jawan Brothers Medical publisher (p) Ltd, New Delhi, India: 111-120p.

-Kobets, T.; Havelkova, H.; Grekov, L. Volkova, V.; Vojtiskova, J.; Svobodova, M.; Demank, P. \&Lipoldova , M. (2012). Genetic of host response to Leishmaniatropica in mice different control to skin pathology, chemokine reaction and invasion in spleen and liver. POLS Neglected Tropical Disease, 6(6): e1667-e1679. 
-Levi- Schaffer, F.; Temkin, V.; Malamud, V.; Feld, S \&Ziberman, y. (1998). Mast cells enhance eosinophil survival in vitro: role of TNF- $\alpha$ and granulocytemacrophage colony stimulating factor. Journal of Immunology, 160(11)5:5554-5562.

-Liu, X.; Walton, S.F.; Murrany, H.C.; king, M. Kelly, A.; Holt, D.C.; Currie , B.J.; Mccarthy, J.S.\&Mounsey, K. E.(2014). Crusted scabies in associated with IL17 secretion by skin T cell. Parasite Immunology, 36(11): 594-604.

-Martin JC, Baeten DL, Josien R (2014) Emerging role of IL-17 and Th17 cells in systemic lupus erythematosus. ClinImmunol 154: 1-12. pmid:24858580

-Morgan, M.S. \&Arlian, L.G. (2010). Response of human skin equivalent to Sarcoptesscabiei. Journal of Medical Entomology, 47 (5): 877-883.

-Morgan, M.S.; Arlian, L.G \& Markey, M.P. (2013). Sarcoptesscabiei mites modulate gene expression in human skin equivalents. PLOS ONE, 8(8): e71143, doi: 10.137/Journal pone.0071143.

-Morsy, T.A.;elAlfy, M.S.; Arafa, M.A.; Salama, M.M \& Habib, K.S. (1995). Serum levels of tumor necrosis factor alpha (TNF- $\alpha$ ) versus immunoglobulin (IgG, Ig MandIgE) in Egyptian scabitic children. Journal of Egyption Society Parasitology, 25(3):773-788.

-Mounsey , K.E.; Murray, H.C.; Belefeld- Ohmann, H.; Pasay, C., Holt, D.C.; Currie, B.J.; Walton, S.F. \&Mccarthy, J.S. (2015) prospective study in a porcine model of Sarcoptesscabiei indicates the association of Th2 and Th1 pathways with the clinical severity of scabies. PLOS Neglected Tropical Diseases Journal, 498: 117.

-Mullins, J.S.; Arlian, L. G. \& Morgan; M.S. (2009). Extracts of Sarcoptesscabiei down modulate secretion of IL-8 by skin keratinocytes and fibroblast in the presence of proinflammatory cytokines. Journal of Medical Entomology, 46(4): 845-851.

-Nimmervoll, H.; Hoby, S.; Robert, N.; Lommano, E.; Welle, M. and Ryser-Degiorgis, M. P. (2013). Pathology of sarcoptic mange in red foxes (Vulpesvulpes): macroscopic and histologic characterization of three disease stages. Journal of Wildlife Disease, 49(1):91-102.

-Pence, DB \&Veekermann,E. (2002). Sarcoptic manage in wild life. Revue Scienifique et Technique deLOIE.,33(2):413-420 
-Portugal, M.; Barak, V.: Ginsburg. I. \& Kohen, R. (2007). Interplay among oxidants, ant: oxidants, and cytokines in skin disorders: present status and future considerations. Biomedicine and Pharmacotherapy, 61(7):412-422.

-Poulat, A .\&Nasirian, H. (2007). Prevalence of pediculosis and scabies in prisoners of Bander Abbas, Hormozgan province, Iran. Pakistan Journal of Biological Sciences, 10(21): 3967-3969.

-Routh, H.B. Mirensky, Y, M.; Parish, C.C. \&Witkows, J.A. (1994). Ectoparasites as sexually transmitted diseases. Seminar Dermatology, 13(4):243-244.

-Smets, K. and vercruysse, J. (2000). Evaluation of different methods for the diagnosis of scabies in swine. Veterinary parasitology, 90(2):137-145.

-Toet, H. M.; Fischer, K.; Mounsey, K. E.; Sandeman, R. M., Autoantibodies to ironbinding proteins in pigs infested with Sarcoptesscabiei, Veterinary Parasitology (2014),http://dx.doi.org/10.1016/j.vetpar.2014.07.012

-Walton, S.F.; Holt, D.C.; Currie, B.J. \& Kemp, D.J. (2004). Scabies: new future for neglected disease. Advances in Parasitology, 57: 309-317.

-Walton, S.F.; Pizzuto, S.: Slender, A.: Viberg, L.; Holt, D..' Hales, B.J.; kemp, D.J., currie, B.J; Rolland, J.M \&O'Hehir, R.(2010). Increased allergic immune response to Sarcoptesscabiei antigens in crusted versus ordinary scabies. Clinical and Vaccine Immunology, 17(9): 1428-1438.

-White, J.J. (2009). The veron community scabies education and eradication program. $\mathrm{Ph}$. D. Thesis, Faculty of Virginia polytechnic institute and state university: 102p.

-Word health organization. (2005). Epidemiology and management of common skin diseases in children in developing countries. Geneva: World Health Organization, Depart men of Child and Adolescent Health and Development. WHO/FCH/CAH/05-12:62p.

-Zamorano, J.: Rivas, M.D.\& Perez, M. (2003). Interlukine-4: a multi- functional cytokine. Immunologia, 22(2):215-224. 